\title{
Secondary Structure of Butyrylcholinesterase
}

\author{
Srinivas $\mathbf{K}^{1}$, Sridhar $\mathbf{G R}^{2 *}$ and Appa Rao Allam ${ }^{3}$
}

${ }^{1} V$ R Siddhartha Engineering College, Vijayawada, India

${ }^{2}$ Endocrine and Diabetes Centre, Visakhapatnam, India

${ }^{3}$ C R Rao Advanced Institute for Mathematics, Statistics \& Computer Science (AIMSCS), University of Hyderabad Campus, India

\begin{abstract}
Objective: Butyrylcholinesterase, a protein from the esterase family of enzymes, has been shown to modulate the expression of insulin resistance syndrome. In order to identify related proteins with more well established functions, the current in silico work was done to delineate the secondary structure of the enzyme and compare it with other proteins of similar structure. The purpose was to predict possible role(s) of BchE in comparison to related proteins based on their secondary structures.
\end{abstract}

Methods: With the input as amino acid sequences of BchE, we obtained the secondary structure using the SOPM tool. From the Protein Data Bank (PDB) database we compared the secondary structure of BchE with those having $65 \%$ or more similarity.

Results: We obtained 13 sequences: Acetylcholinesterase (EC 3.1.1.7, PDB 1gqr; score 72.134), Fasciculin 2 mouse acetylcholinesterase complex $1 \mathrm{MAH} 3$, PDB $1 \mathrm{mah}$; score 71.806), AT sulfurase from penicillium chrysogenum, 1i2d; score 67.9727), pyruvate kinase (1a3w; score 67.5503), thronine synthase from Arabidopsis thaliana (1e5x; score 67.426), DNA repair UVRB in complex with ATP (1d9z; score 66.778), hyperthermophilic tungstopterin enzyme (1aor; score 66.28), xanthine oxidase from bovine milk (1fiq; score 66.147), alpha D-glucoronidase from Bacillus stearothermophius (1k9d; score 65.959), ribonuclease inhibitor-angiogenin complex (1a4y; score 65.913), hemochromatosis protein HFE complexed with transferrin receptor (1de4; score 65.723), K217e variant of Klebsiella aerogenes urease (1a5k; score 65.667), phosphoenolpyruvase carboxykinase in complex with ADP, A1F3 and pyruvate (1k3c; score 65.5233$)$. Their functions ranged from catalyzing acetylcholine to sulfate asimilation, glycolysis, nucleic acid binding, oxidoreductase activity, iron sulfur cluster binding, xanthine oxidation, cation binding, urease activity and phosphoenolpyruvate carboxykinase activity. They are present in both the cytoplasm, extracellular compartment and cytoplasmic membranes.

Conclusion: We compared the predicted secondary structure of butyrylcholinesterase and obtained 13 proteins with at least $65 \%$ similarity that are found in the cytoplasm and extracellular regions, with catabolic, synthetic, electron transport and immune processing.

Keywords: In silico; Protein Data Bank (PDB)

\section{Introduction}

Proteins are key components in communication, metabolism and structure in biological processes. The structure of proteins is conventionally obtained by eleborate and complex methods such as X-ray crystallography, NMR and Raman spectroscopy. Though difficult to execute, they form the gold standard for comparison.

The omics revolution has provided an abundance of publicly available data. It is not practical to apply traditional biological methods to classify and annotate them structurally and functionally.

More rapid, automated in silico methods have therefore been developed to derive meaning from the sea of data. Given that the amino acid sequences are known and the force character of each molecule is available, physical and chemical computational methods should be able to predict the protein structure based on the amino acid sequences.

In this study we employed in silico method to predict the secondary structure of butyrylcholinesterase, a protein that is well characterized structurally, but with poorly defined physiological functions. Comparisons can be performed at various levels in biological organization, eg comparing the nucleotide sequences and constructing phylogenic trees to ascertain possible evolutionary origin and function [1].

Butyrylcholinesterase is an enzyme that is involved in the phenotypic expression of insulin resistance and metabolic syndrome [2]. It belongs to the esterase family of enzymes, in which acetylcholinester- ase (AChE) is an important regulator of neuromuscular activity. The two members share structural similarity, although the functional significance of BChE is not as well characterized as it is for AChE. Other than its specific role in hydrolyzing succinylcholine, a muscle relaxant given in general anesthesia, the other functions generally relate to hydrolysis of cocaine, of pesticides and as a prophylactic agent in future exposure to biochemical warfare agents [3-5]. Because it is produced in the liver, circulates in the blood stream, and is present at higher levels than AChE, a toxicological role for BChe has been attributed.

In addition it is affected by dietary lipids, changes in body weight and in diabetes mellitus $[2,3,6,7]$. The development of succinylcholine induced apnea in individuals with variant forms of the enzyme is the only well established phenotypic expression of the enzyme [6]. Despite its functional relationship to the neuromusclular enzyme acetylcholinesterase, the physiological roles of BchE are not well established. The advent of the genomics era allowed in silico studies to compare the re-

*Corresponding author: Sridhar GR, Endocrine and Diabetes Centre, 15-12-15 Krishnanagar, Visakhapatnam 530 002, India, E-mail: sridharvizag@gmail.com

Received May 14, 2012; Accepted June 20, 2012; Published June 25, 2012

Citation: Srinivas K, Sridhar GR, Allam AR (2012) Secondary Structure of Butyrylcholinesterase. J Diabetes Metab 3:199. doi:10.4172/2155-6156.1000199

Copyright: ( 2012 Srinivas K, et al. This is an open-access article distributed under the terms of the Creative Commons Attribution License, which permits unrestricted use, distribution, and reproduction in any medium, provided the original author and source are credited. 
Citation: Srinivas K, Sridhar GR, Allam AR (2012) Secondary Structure of Butyrylcholinesterase. J Diabetes Metab 3:199. doi:10.4172/21556156.1000199

Page 2 of 6

lationship of proteins with other proteins with known functions, and infer their possible physiological roles. Using phylogenetic analysis, we had shown that BchE exists in life forms across the spectrum, implying it could have an evolutionarily conserved role [1]. We also showed that it could play a role in the etiology of insulin resistance and the coexistence of Alzheimer's disease and type 2 diabetes mellitus through oxidative stress $[8,9]$.

In this presentation we predict the secondary structure of BchE; by using bioinformatics tools to compare the structure with other proteins in Protein Databank (PDB) and ascertain its possible role vis a vis other proteins with similar structure(s).

\section{Methods and Results}

\section{Secondary structure prediction}

$\mathrm{BChE}$ protein information and its sequence is retrieved from the UniProtKB/Swiss-Prot with entry P06276. Figure 1 shows the BChE sequence and its information. FASTA formatted BChE human protein sequence was entered into self-optimized prediction method (SOPM) to obtain the secondary structure. Figure 2 shows the secondary structure of $\mathrm{BChE}$ along with its protein sequence.

The following sequence of BChE (i.e P06276)/ Structure (PDB id: 2pm8) was shown to interact with ApoE (PDB id: 1nfn), PON1 (PDB id: 1v04) and ATP (sequence id: Q9Y487):

$>$ sp|P06276|CHLE_HUMAN Cholinesterase OS=Homo sapiens $\mathrm{GN}=\mathrm{BCHE} \mathrm{PE}=1 \mathrm{SV}=1$

MHSKVTIICIRFLFWFLLLCMLIGKSHTEDDIIIATKNGKVRGMNLTVFGGTVTAFLGIP
YAQPPLGRLRFKKPQSLTKWSDIWNATKYANSCCQNIDQSFPGFHGSEMWNPNTDLSEDC

LYLNVWIPAPKPKNATVLIWIYGGGFQTGTSSLHVYDGK FLARVERVIVVSMNYRVGALG

FLALPGNPEAPGNMGLFDQQLALQWVQKNIAAFGGNPKSVTLFGESAGAASVSLHLLSPG

SHSLFTRAILQSGSFNAPWAVTSLYEARNRTLNLAKLTGCSRENETEIIKCLRNKDPQEI

LLNEAFVVPYGTPLSVNFGPTVDGDFLTDMPDILLELGQFKKTQILVGVNKDEGTAFLVY

GAPGFSKDNNSIITRKEFQEGLKIFFPGVSEFGKESILFHYTDWVDDQRPENYREALGDV

VGDYNFICPALEFTKKFSEWGNNAFFYYFEHRSSKLPWPEWMGVMHGYEIEFVFGLPLER

RDNYTKAEEILSRSIVKRWANFAKYGNPNETQNNSTSWPVFKSTEQKYLTLNTESTRIMT

KLRAQQCRFWTSFFPKVLEMTGNIDEAEWEWKAGFHRWNNYMMDWKNQFNDYTSKKESCV

GL

\section{Comparison of secondary structure}

In the current presentation we have compared the secondary structure of $\mathrm{BChE}$ with other proteins to impute a common biological function, considering the similarity of secondary structures. However, the authors realize this is a hypothesis-generating proof of concept in silico

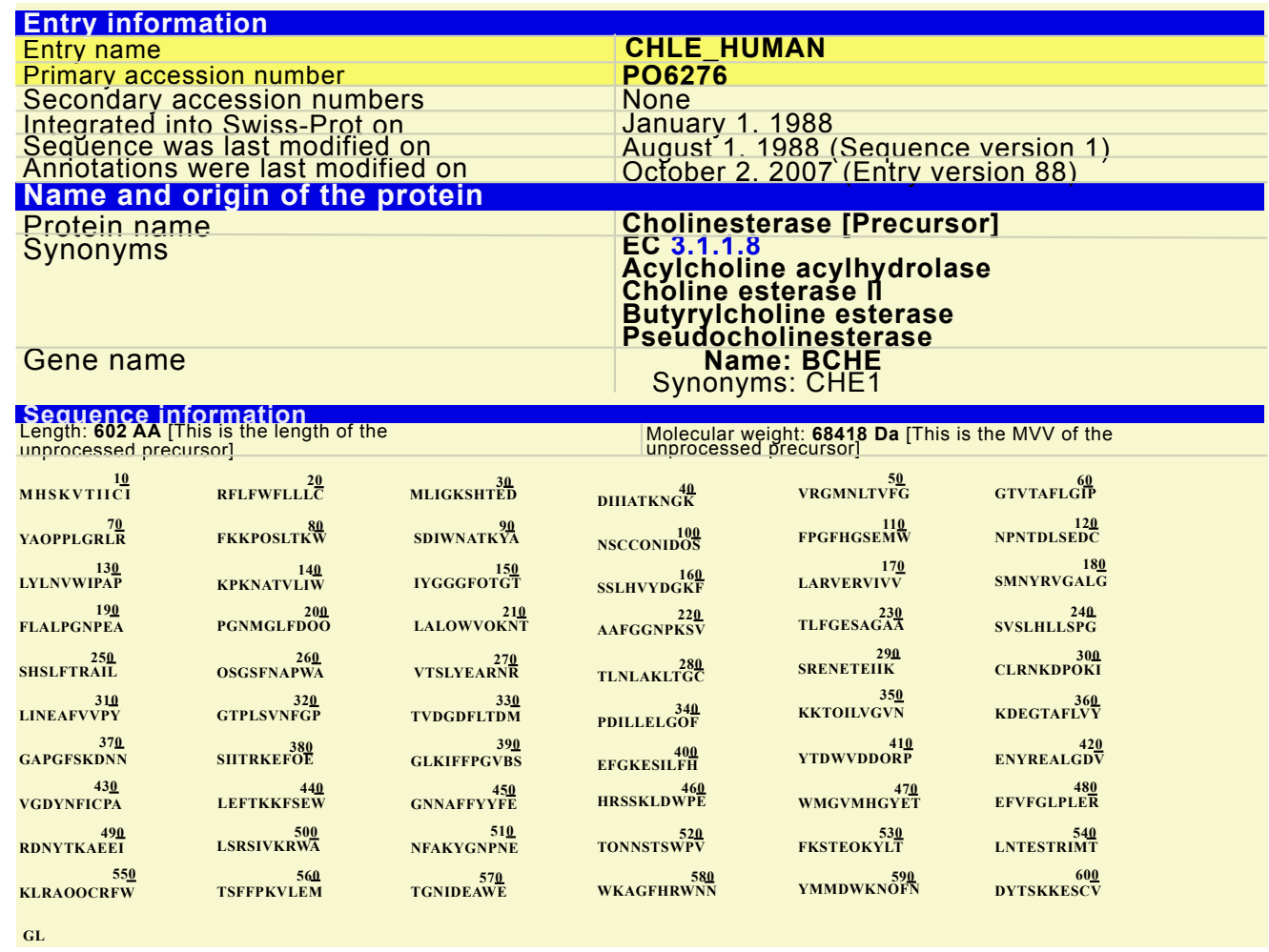

Figure 1: UniPortKB/Swiss-prot entry for BChE Human. 
Citation: Srinivas K, Sridhar GR, Allam AR (2012) Secondary Structure of Butyrylcholinesterase. J Diabetes Metab 3:199. doi:10.4172/21556156.1000199

\begin{abstract}
MHS KV T I I C I RF LF WF L L L CML I GK S HTE DD I I I ATKN GKVRGMNL TVFGGTVT A F L I P Y AQP PLGRL R ccceeee hhhhhhhhhhhheeeccccccceeeeecccceeeeeeeeccee eeeccccccccccee e F K KP QS L T KWS D I WNA TKYANS C C QN I DQSF P GF HG S E MWNPN T DL S E DC L YL NVWIP AP K P KN A TV L I W

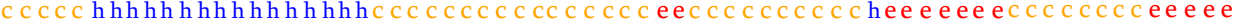
I YG G GF Q T G T S S L H VY DG K F L A RV E R V IV V SMN Y RV G AL G F L A L P GN P E AP G NMG L F DQQ L A L QWVQ KN I

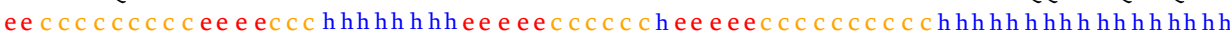
AA F G GN P K SV T L F G E S AG AA S V S L H L L S PG S H S L F T R A I L QS G S F N APWA V T S L Y E AR N RT L N L A KL T G C

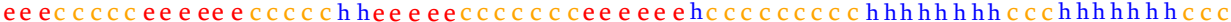
SR E N E T E I I K C L R N KD P QE I L L N E AF V V P YG T P L S V NF G P T V DG DF L T DMP D I L L L GQF KK T QI L VG VN c c c c hhhhhhhhccccc cheee h hheeeccccceeeecccccccehhccchhhhhhcccccceeeeec KD E G T AF L VY GA P GF S KD NN S I I T R KE F OE G L K I F F P G V S E F G KE S I L F H Y TDWVD DQRP E N Y R E AL G DV CCCCcee ee C C C C C C C e e e hhhhhhhhhee C C C C C C C cheeeeh hh C C C C C Chhhhhhhh h V GD YN F I C P A L E F T K K F S E WGNN A F F Y Y F E HR S S K L P WP EWMGV MHG YE I EF V F G L P L E R R DN Y TK A E E I hh c c c c c c hhhhhhhhhhccccee eee c c c c c c c ch hee hccccee ee ecc c c c c c hhhhhhh L S R S I V K RWAN F AK Y GN P NE TONN S T SWPVF K S T E OK YL T LN T E S T R I M T KL R AQOC RF WT SFF P K V L E M

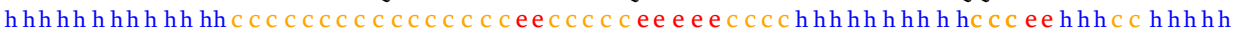
TGN I DE AEWEWK A GF HRWNN Y MMDWK NQF N DY T S K KE S CV GL

c C C C hhhhhhhhhhcchhhheee hhhhcchhcccccccee
\end{abstract}

$\begin{array}{lll}\text { Alpha helix } \quad(\mathrm{Hh}) & : 190 \text { is } 31.56 \% \\ \text { Extended strand }(\mathrm{Ee}) & : 143 \text { is } 23.75 \% \\ \text { Random coil } \quad(\mathrm{Cc}) & : 269 \text { is } 44.68 \%\end{array}$
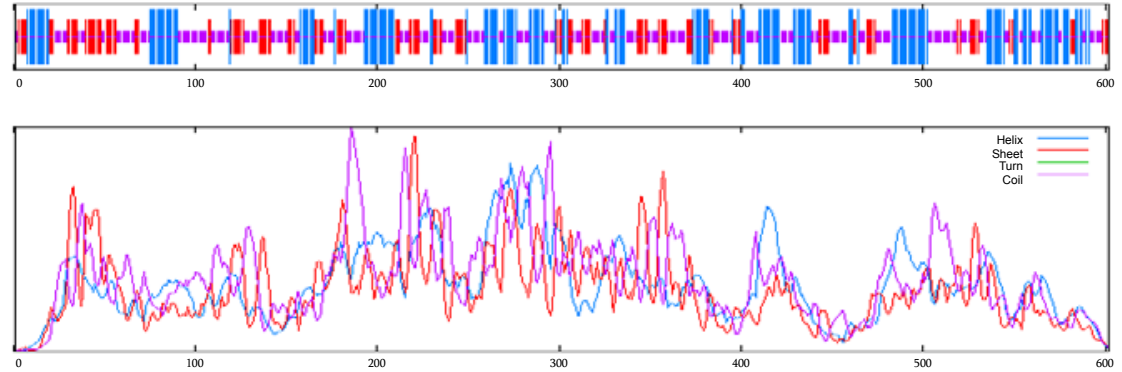

Figure 2: BChE Secondary Structure as well as its sequence.

study, which is to our knowledge, is the first comparison published for this purpose. This must be further studied both in silico by comparison of tertiary and quarternary structures, as well as pathway analysis and protein-protein interaction to further refine the possible functional role that can be verified by biological methods.

By using secondary structure of BChE to search for similar structures in PDB library, thirteen structures with different species have been identified. To infer the functionality for assigning BChE protein, in accordance with the similarity and Z-score values, pair-wise alignment has been implemented between BChe structure with all these thirteen structures. Figure 3 shows the pair wise alignment of BChE secondary structure with 1gqr secondary structure and their structure similarity.

>1gqr ACETYLCHOLINESTERASE (E.C. 3.1.1.7) COMPLEXED WITH RIVASTIGM...

Z-Score: 2.20

Normalized score: 72.134

Experimental residue alignment:

Length 602

Length 532

By using the literature survey, the functionalities of thirteen species have been collected, analyzed and given in tabular form. The Table gives information about functionalities of these species.

\section{Discussion}

Our approach to secondary structure prediction is based on using the sequence of proteins as an interlingua between the different identifiers. This strategy allows, our secondary structure prediction platform to integrate data from multiple sources into a single structure, while allowing the user to control which sequences are used in the prediction.

Genomic data from sequencing projects can be used for biological and clinical research only if the functional information can be extracted from them and biological data can be converted into 'knowledge of biological systems' [10]. Butyrylcholinesterase lends itself as a prototype for such analysis.

Here we have shown that the secondary structure of butyrylcholinesterase had similar structures distributed across the biological spectrum ranging from plants to fish, bacteria, fungi and mammals [11-20]. This is consonant with our earlier report where BchE related sequences were shown to be present in a similar wide spectrum of life forms [1].

The known functional roles of proteins ranged across a broad sweep of physiological processes including the catalysis of final steps in glycolysis [17], threonine formation [11], urate formation [19] and the binding of a key protein in angiogenesis [20]. The active sites of proteins also ranged from acetylcholinesterase with a deep narrow gorge [12] to that of hyperthermophilic aldehyde ferredoxin oxidoreductase, which shares the properties of multicentric redox proteins [13]. 


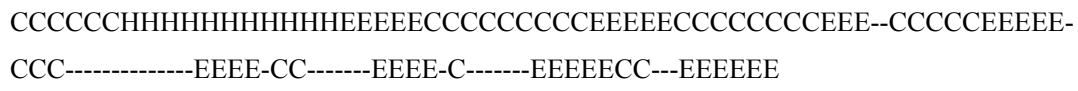

Figure 3: Pair wise alignment of $B C h E$ with 1gdr.

Evolutionarily, a study of related proteins shows they are conserved from bacteria to humans and have homologous structure across various sources [19], and have vestigial features of bifunctional ancestor of fungal sulfurylase [16]. Divergence of active site is suggested, as well as sequence identify at the erythroid cells compared to others [18].

Structural similarities among proteins are associated with functional relationship and with being part of the same functional network [21]. Earlier we showed that butyrylcholinesterase formed a network with related proteins including dehydrogenases (ALDH9A1, PDHX), ATPase (ATP6VOA2) and peraoxanase (PON1), besides acetylcholinesterases [19]. Based on their similarity, butyrylcholinesterase may have putative roles in maintaining cell growth and a supplementary role to acetylcholinesterase in neural function $[22,8]$.
Evidence is available for the modulatory role of butyrylcholinesterase in different components of the metabolic syndrome [23]. The current study provides further leads to understanding its relation to other proteins similar in their secondary structure. A confluence of in silico and in vitro methods will be able to increase possibly new indications for therapeutic use of the protein [2].

The information has been annotated from published biological investigations. The purpose of this in silico work is to provide proof-ofcon $[7,8]$ and that it may be applied for the study of other proteins with poorly characterized functions.

In summary proteins present in the cytoplasm, extracellular compartment and cytoplasmic membranes share secondary structure simi- 
Citation: Srinivas K, Sridhar GR, Allam AR (2012) Secondary Structure of Butyrylcholinesterase. J Diabetes Metab 3:199. doi:10.4172/21556156.1000199

Page 5 of 6

\begin{tabular}{|c|c|c|c|c|c|c|}
\hline PDB id & Species Name & Score & Z-score & Biological Functions & Molecular Functions & Cellular Components \\
\hline $1 \mathrm{gqr}$ & SPECIES OF ELECTRIC RAY & 72.134 & 2.20 & $\begin{array}{l}\text { acetylcholinesterase activity } \\
\text { cholinesterase activity }\end{array}$ & $\begin{array}{l}\text { acetylcholine catabolic } \\
\text { process in synaptic cleft }\end{array}$ & \\
\hline $1 \mathrm{mah}$ & MOUSE & 71.8062 & 2.18 & cholinesterase activity & & Extracellular region \\
\hline $1 \mathrm{i} 2 \mathrm{~d}$ & $\begin{array}{l}\text { CRYSTAL STRUCTURE OF ATP } \\
\text { SULFURYLASE FROM PENICILLIUM } \\
\text { CHRYSOGENUM }\end{array}$ & 67.9727 & 1.92 & $\begin{array}{l}\text { Sulfate adenylyltransferase (ATP) activity } \\
\text { ATP binding } \\
\text { kinase activity } \\
\text { transferase activity, } \\
\text { transferring phosphorus-containing groups }\end{array}$ & sulfate assimilation & \\
\hline 1a3w & $\begin{array}{l}\text { PYRUVATE KINASE FROM SAC- } \\
\text { CHAROMYCES CEREVISIAE } \\
\text { COMPLEXED WITH FBP, PG, MN2+ } \\
\text { AND K+ }\end{array}$ & 67.5503 & 1.89 & $\begin{array}{l}\text { magnesium ion binding } \\
\text { pyruvate kinase activity } \\
\text { potassium ion binding }\end{array}$ & glycolysis & \\
\hline $1 e 5 x$ & $\begin{array}{l}\text { STRUCTURE OF THREONINE } \\
\text { SYNTHASE FROM ARABIDOPSIS } \\
\text { THALIANA }\end{array}$ & 67.4264 & 1.89 & $\begin{array}{l}\text { catalytic activity } \\
\text { threonine synthase activity } \\
\text { pyridoxal phosphate binding }\end{array}$ & $\begin{array}{l}\text { amino acid metabolic } \\
\text { process } \\
\text { metabolic process } \\
\text { threonine biosynthetic } \\
\text { process }\end{array}$ & \\
\hline $1 \mathrm{~d} 9 \mathrm{z}$ & $\begin{array}{l}\text { CRYSTAL STRUCTURE OF THE DNA } \\
\text { REPAIR PROTEIN UVRB IN COM- } \\
\text { PLEX WITH ATP }\end{array}$ & 66.7785 & 1.84 & $\begin{array}{l}\text { nucleic acid binding } \\
\text { DNA binding } \\
\text { helicase activity } \\
\text { ATP binding } \\
\text { excinuclease ABC activity } \\
\text { hydrolase activity }\end{array}$ & nucleotide-excision repair & $\begin{array}{l}\text { cytoplasm } \\
\text { excinuclease repair } \\
\text { complex }\end{array}$ \\
\hline 1aor & $\begin{array}{l}\text { STRUCTURE OF A HYPERTHERMO- } \\
\text { PHILIC TUNGSTOPTERIN ENZYME, } \\
\text { ALDEHYDE FERREDOXIN OXIDO- } \\
\text { REDUCTASE }\end{array}$ & 66.28 & 1.81 & $\begin{array}{l}\text { oxidoreductase activity, } \\
\text { acting on the aldehyde or oxo group of } \\
\text { donors, } \\
\text { iron-sulfur protein as acceptor } \\
\text { iron-sulfur cluster binding }\end{array}$ & electron transport & \\
\hline 1 fiq & $\begin{array}{l}\text { CRYSTAL STRUCTURE OF XAN- } \\
\text { THINE OXIDASE FROM BOVINE } \\
\text { MILK }\end{array}$ & 66.147 & 1.80 & $\begin{array}{l}\text { xanthine dehydrogenase activity } \\
\text { xanthine oxidase activity } \\
\text { electron carrier activity } \\
\text { oxidoreductase activity } \\
\text { metal ion binding } \\
\text { FAD binding } \\
\text { iron-sulfur cluster binding }\end{array}$ & electron transport & \\
\hline $1 \mathrm{k} 9 \mathrm{~d}$ & $\begin{array}{l}\text { A CRYSTAL STRUCTURE OF ALPHA- } \\
\text { D-GLUCURONIDASE, A FAMILY- } 67 \\
\text { GLYCOSIDE HYDROLASE FROM } \\
\text { BACILLUS STEAROTHERMOPHILUS } \\
\text { T-1 }\end{array}$ & 65.9591 & 1.79 & $\begin{array}{l}\text { catalytic activity } \\
\text { cation binding } \\
\text { alpha-glucuronidase activity }\end{array}$ & $\begin{array}{l}\text { carbohydrate metabolic } \\
\text { process } \\
\text { xylan catabolic process }\end{array}$ & extracellular region \\
\hline $1 \mathrm{a} 4 \mathrm{y}$ & $\begin{array}{l}\text { RIBONUCLEASE INHIBITOR-ANGIO- } \\
\text { GENIN COMPLEX }\end{array}$ & 65.9134 & 1.79 & $\begin{array}{l}\text { protein binding } \\
\text { nucleic acid binding } \\
\text { pancreatic ribonuclease activity }\end{array}$ & & \\
\hline 1de4 & $\begin{array}{l}\text { HEMOCHROMATOSIS PROTEIN HFE } \\
\text { COMPLEXED WITH TRANSFERRIN } \\
\text { RECEPTOR }\end{array}$ & 65.7235 & 1.77 & & $\begin{array}{l}\text { immune response } \\
\text { antigen processing and } \\
\text { presentation }\end{array}$ & $\begin{array}{l}\text { membrane } \\
\text { MHC class I protein } \\
\text { complex }\end{array}$ \\
\hline $1 \mathrm{a} 5 \mathrm{k}$ & $\begin{array}{l}\text { K217E VARIANT OF KLEBSIELLA } \\
\text { AEROGENES UREASE }\end{array}$ & 65.6678 & 1.77 & $\begin{array}{l}\text { urease activity } \\
\text { nickel ion binding } \\
\text { hydrolase activity, } \\
\text { acting on carbon-nitrogen (but not peptide) } \\
\text { bonds }\end{array}$ & $\begin{array}{l}\text { nitrogen compound meta- } \\
\text { bolic process } \\
\text { urea metabolic process }\end{array}$ & \\
\hline $1 \mathrm{k} 3 \mathrm{c}$ & $\begin{array}{l}\text { PHOSPHOENOLPYRUVATE CAR- } \\
\text { BOXYKINASE IN COMPLEX WITH } \\
\text { ADP, ALF3 AND PYRUVATE }\end{array}$ & 65.5233 & 1.76 & $\begin{array}{l}\text { phosphoenolpyruvate carboxykinase } \\
\text { activity } \\
\text { phosphoenolpyruvate carboxykinase } \\
\text { (ATP) activity } \\
\text { ATP binding } \\
\text { purine nucleotide binding }\end{array}$ & gluconeogenesis & \\
\hline
\end{tabular}

Table 1: Protein with similar secondary structures. 
Citation: Srinivas K, Sridhar GR, Allam AR (2012) Secondary Structure of Butyrylcholinesterase. J Diabetes Metab 3:199. doi:10.4172/21556156.1000199

Page 5 of 5

larity with butyrylcholinesterase and participate in catabolic, synthetic, electron transport and immune processing.

\section{References}

1. Sridhar GR, Lakshmi PV, Rao AA (2006) Phylogenetic tree construction of butyrylcholinesterase sequences in life forms. J Assoc Physicians India 54: 122-123.

2. Sridhar GR (2011) Proteins of the Esterase Family: Patents for Some Proteins in Search of Metabolic Functions. Recent Patents on Biomarkers 1: 205-212.

3. Taylor P (1991) The cholinesterases. J Biol Chem 266: 4025-4028.

4. Goodall R, Association of Clinical Biochemists Analytical Investigations Standing Committee (2004) Cholinesterase: phenotyping and genotyping. Ann Clin Biochem 41: 98-110.

5. Randell EW, Mathews MS, Zhang H, Seraj JS, Sun G (2005) Relationship between serum butyrylcholinesterase and the metabolic syndrome. Clin Biochem 38: 799-805

6. Sridhar GR, Nirmala G (2002) Inborn errors in lipid metabolism. In: Tripathy BB Das S (Eds) Lipid Disorders. Association of Physicians of India, API College of Physicians 59-80.

7. Sridhar GR, Nirmala G, Apparao A, Madhavi AS, Sreelatha S, et al. (2005) Serum butyrylcholinesterase in type 2 diabetes mellitus: a biochemical and bioinformatics approach. Lipids Health Dis 4: 18.

8. Sridhar GR, Thota H, Allam AR, Suresh Babu C, Siva Prasad A, et al. (2006) Alzheimer's disease and Type 2 diabetes mellitus: the cholinesterase connection? Lipids Health Dis 5: 28.

9. Rao AA, Sridhar GR, Das UN (2007) Elevated butyrylcholinesterase and acetylcholinesterase may predict the development of type 2 diabetes mellitus and Alzheimer's disease. Med Hypotheses 69: 1272-1276.

10. Mazumder R, Vasudevan S (2008) Structure-guided comparative analysis of proteins: principles, tools, and applications for predicting function. PLoS Comput Biol 4: e10000151.

11. Thomazeau K, Curien G, Dumas R, Biou V (2001) Crystal structure of threonine synthase from Arabidopsis thaliana. Protein Sci 10: 638-648.

12. Sussman JL, Harel M, Frolow F, Oefner C, Goldman A, et al. (1991) Atomic structure of acetylcholinesterase from Torpedo californica: a prototypic acetylcholine-binding protein. Science 253: 872-879.

13. Chan MK, Mukund S, Kletzin A, Adams MW, Rees DC (1995) Structure of a hyperthermophilic tungstopterin enzyme, aldehyde ferredoxin oxidoreductase. Science 267: 1463-1469.

14. Jabri E, Carr MB, Hausinger RP, Karplus PA (1995) The crystal structure of urease from Klebsiella aerogenes. Science 268: 998-1004.

15. Sudom AM, Prasad L, Goldie H, Delbaere LT (2001) The phosphoryl-transfer mechanism of Escherichia coli phosphoenolpyruvate carboxykinase from the use of AIF (3). J Mol Biol 314: 83-92.

16. MacRae IJ, Segel IH, Fisher AJ (2001) Crystal structure of ATP sulfurylase from Penicillium chrysogenum: insights into the allosteric regulation of sulfate assimilation. Biochemistry 40: 6795-6804.

17. Jurica MS, Mesecar A, Heath PJ, Shi W, Nowak T, et al. (1998) The allosteric regulation of pyruvate kinase by fructose-1,6-bisphosphate. Structure 6: 195210.

18. Rachinsky TL, Camp S, Li Y, Ekstrom TJ, Newton M, et al. (1990) Molecular cloning of mouse acetylcholinesterase: tissue distribution of alternatively spliced mRNA species. Neuron 5: 317-327.

19. Enroth C, Eger BT, Okamoto K, Nishino T, Nishino T, et al. (2000) Crystal structures of bovine milk xanthine dehydrogenase and xanthine oxidase: structurebased mechanism of conversion. Proc Natl Acad Sci USA 97: 10723-10728.

20. Papageorgiou AC, Shapiro R, Acharya KR (1997) Molecular recognition of human angiogenenin by placental ribonuclease inhibitor - an X-ray crystallographic study at 2.0 A resolution. EMBO J 16: 5162-5177.

21. Vazquez, Flammini A, Maritan A, Vespignani A (2003). Global protein function prediction from protein-protein interaction networks. Nat Biotechnol 21: 697700

22. Appa Rao A, Srinivas K, Rajender R, Das UN (2008) Prediction of butyrylcholinesterase function through domain analysis and protein-protein interaction. Curr Nutr Food Sci 4: 176-184.

23. Sridhar GR, Rao AA, Srinivas K, Nirmala G, Lakshmi G, et al. (2010) Butyrylcholinesterase in metabolic syndrome. Med Hypotheses 75: 648-651. 